\title{
Soil contamination with heavy metals in the sh. Rashidovsky district of Jizzakh region and methods of their decrease from the soil composition
}

\author{
Dildora Sh. Berdieva* \\ Jizzakh Polytechnic Institute, 100130, Jizzakh, Uzbekistan
}

\begin{abstract}
Sh. Rashidovsky district is one of the territories where the quality of agricultural land has decreased, the main land of the district is located near the city center, industrial enterprises pollute the soil with various pollutants, the natural balance is disturbed and the ecological environment is polluted. During the survey of soil pollution with heavy metals, the concentration of heavy metals in the soil in the layers $(0-10,10$ $20,20-30,30-40,40-50,50-60,60-70 \mathrm{~cm}$ ) of agricultural land was analyzed. Analysis of soil contamination with heavy metals in the territory shows that a slight increase in the MCL for soils was observed for cuprum, zinc, chromium, nickel, cobalt and arsenic. The increase occurred mainly in the upper layer of 0-30 centimeters. The concentrations of all other heavy metals do not exceed the MCL, which confirms the conclusions drawn in the review section of the study on the low informative value of heavy metals in environmental monitoring. To reduce the negative impact of heavy metals on the light gray lands of the Sh. Rashidov region, it is necessary to apply mineral fertilizers, grow crops that are resistant to pollution.
\end{abstract}

\section{Introduction}

Currently, the problem of soil pollution with heavy metals is relevant in the technogenic and agricultural sectors. Heavy metals are among the main pollutants in the environment. Many substances of this group, such as lead, copper, zinc, cadmium, can cause immunological, oncological and other diseases, even in very small quantities. Studies by scientists from different countries have shown that about $70 \%$ of heavy metals enter the human body with food [1].

Sorption cleaning of soils from heavy metals studied by A.I. Vezentsev and others [2]. The article presents the results of a study of the ability of clays of the Belgorod region to absorb $\mathrm{Pb}$ (II) and $\mathrm{Cu}$ (II) ions from water and buffer soil hoods. In the course of the experiment, the optimal ratio of clay: soil was established, at which the cleaning of the soil from heavy metals is most effective. These authors have not studied soil cleaning with other types of heavy metals.

\footnotetext{
*Corresponding author: Taylakov1964@mail.ru
} 
The composition of heavy metals in the soils of the Mangistau region was studied Pavlichenko L.M. et al., 2016 [3]. Analysis of soil data and soil maps of the Mangistau region made it possible to identify the main factors affecting the level of their ecological degradation, to identify the main types of soil pollution and salinization. Indicators on soil bonitet in the region are very low, which is associated with a low humus content in zonal soils and the presence of negative signs of increased salinity. Only in some parts of the province used for irrigated arable land are the quality indicators higher. In this study, it was determined that heavy metals such as cadmium, copper, lead and zinc are higher than the permissible concentration [3]. The rest of the types of heavy metals in the soil have not been fully studied by them.

Heavy metals of soils from exhausted deposits at the Zauralsky Bashkir mine (studies by Gazizov L.R. et al., 2009) to determine soil contamination with heavy metals $\mathrm{Cu}, \mathrm{Zn}, \mathrm{Fe}$, $\mathrm{Mn}, \mathrm{Co}, \mathrm{Cd}, \mathrm{Pb}, \mathrm{Ni}$. The reasons for the increase in the permissible concentration of these heavy metals are not fully understood [4].

In 2018-2019, she developed a set of indicators for the main properties of gypsum soils and seasonal dynamics of biological activity, indicators of degradation on the topic "Gypsum soils of the Jizzakh desert and their biological activists" in the Jizzakh region Makhkamova D. Yu. A researcher at the biological faculty of the National University of Uzbekistan [5].

Researcher Z.U.Rakhmatov conducted research on the topic "Development and implementation of methods aimed at preserving, increasing the fertility of irrigated soils in the Jizzakh desert, preventing and controlling salinity and improving all soil properties." In the study, these researchers did not study the contamination of the soils of the Jizzakh region with heavy metals [6].

From the literary analysis of research works, I revealed the following:

The above studies did not study the level of contamination of soils in Jizzakh region with heavy metals and its causes.

In the future, it is necessary to develop scientific and practical recommendations to reduce the pollution of soils in the Jizzakh region with heavy metals, which is important for the region.

The aim of this work is to study changes in the composition of heavy metals in the soil of Sh. Rashidov district of Jizzakh region and the importance of their impact.

\section{MATERIALS AND METHODS.}

\subsection{Survey object.}

The main lands of Sh. Rashidov region are located around the city of Jizzakh and in the northeastern part, which is the administrative center of Jizzakh region. The total area of irrigated land in the district is 34690 hectares, of which: non-saline lands - 8935 hectares $(25.8 \%)$, saline lands - 25755 hectares $(74.2 \%)$. The object of the study was the light gray soils of the Sh. Rashidovsky region (Fig. 1).

Today Sh. Rashidovsky district is one of the territories where the quality of agricultural land has decreased, the main land of the district is located near the city center, industrial enterprises pollute the soil with various pollutants, the natural balance is disturbed and the ecological environment is polluted.

The soils of Sh. Rashidovsky district are light gray, the average humus content in saline soils is $1-1.5 \%$, in saline soils $-1 \%$, which are considered the most fertile soils of the region. The total porosity of serotgrass soils varies in the range of genetic soil layers $(42-56 \%)$, depending on the frequency of irrigation. 
The use of chemicals by people in economic activities and their contribution to the cycle of anthropogenic transformations in the environment is constantly growing [7].

Pollutants according to (GOST 17.4.1.0283) in soil are divided into three classes:

Class I (high risk) - As, Cd, Hg, Se, Pb, F, benz (a) pyrene, Zn;

Class II (moderately hazardous) - B, Co, Ni, Mo, Cu, Sb, Cr;

Class III (low risk) - Ba, V, W, Mn, Sr, acetophenone [8].

Soil pollution with heavy metals is associated with their widespread use in industrial production. Due to imperfect cleaning systems, heavy metals enter the environment, including the soil, polluting and poisoning it.

Soil is the main medium in which heavy metals accumulate. Heavy metals fall to the ground through both atmospheric air and water. It is a secondary source of pollution of the Earth's oceans and the surface atmosphere. Heavy metals can be assimilated through the soil and into food [9].

According to the monitoring results, 9 elements of the periodic table were found in the soil. Including: $\mathrm{Cu}, \mathrm{Zn}, \mathrm{Cr}, \mathrm{Mn}, \mathrm{Ni}, \mathrm{Co}, \mathrm{As}, \mathrm{Cd}, \mathrm{Pb}$.

The largest suppliers of metal-containing waste are enterprises for the smelting of nonferrous metals (aluminum, aluminum oxide, copper-zinc, lead, nickel, titanium-magnesium, mercury, etc.), as well as enterprises for the processing of non-ferrous metals (radio engineering), electrical engineering, instrument making, galvanic sky and others).

\subsection{Sampling process.}

Since the contours of Sh. Rashidovsky district represent certain points that do not change, they were designated as sampling points. This is shown on the area of irrigated land in Sh. Rashidovsky district (Fig. 1). Field sampling was carried out on July 27, 2020.

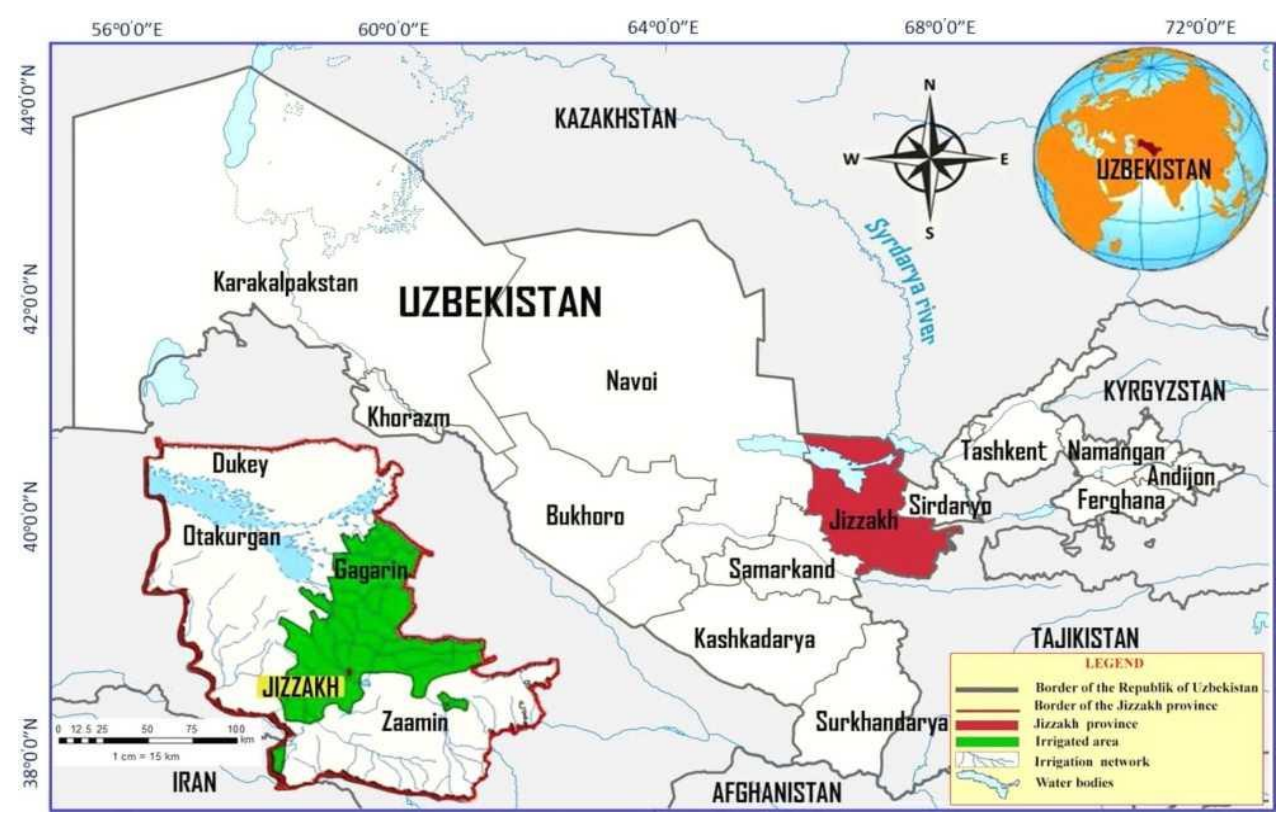

Fig. 1. Object study of Sh. Rashidov district of Jizzakh region

When determining the field composition and assessing the composition of the soil of the Sh. Rashidovsky district during field studies conducted in July 2020, 9 samples of soil layers 0-10, 10-20, 20-30, 30-40, 40-50 were taken from the sample., 50-60 and 50-70 cm. Samples were taken for a 10 -gram beaker. 


\subsection{Applied methods. Sample analysis methods.}

The hydrogen index of the soil composition $\mathrm{pH}$ was determined in the field.

For the analysis of soil samples, atomic absorption, gas chromatographic, photometric, photocolorimetric, gravimetric, spectrophotometric, titrometric and other physicochemical methods were used [10].

Mineralization was determined by gravimetric method. The detection method is based on gravimetric determination of solutes and is determined by filtering the sample to constant weight at low temperature $\left(105-110^{\circ} \mathrm{C}\right)$ for water with low mineral content $\left(105-110^{\circ} \mathrm{C}\right)$ and at $150^{\circ} \mathrm{C}$, evaporation and drying. remainder [10].

Methods for the analysis of heavy metals. Heavy metals are detected by photometric and photocolorimetric methods. For example, the formation of a colored complex compound in the presence of copper xylenol was determined based on the formation reaction of a yellow alkali complex in ferric medium.

According to the results of field and laboratory studies and observations, the sources and the level of soil contamination in Sh. Rashidovsky district were established (Fig. 2).

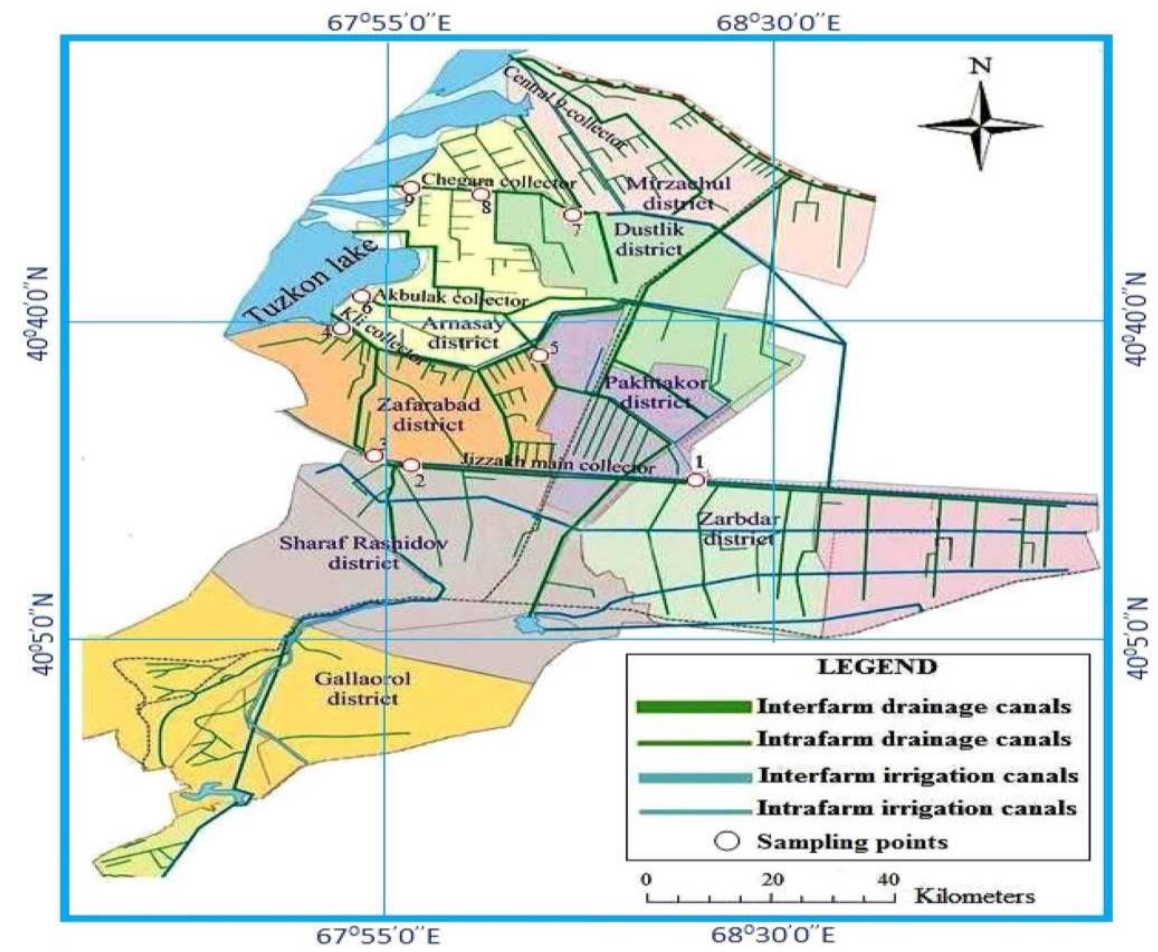

Fig. 2. The object of research is Sh.Rashidovsky district.

\section{Results and discussion}

\subsection{Qualitative indicators of soil of Sh. Rashidovsky district.}

On the basis of the analysis, the qualitative indicators of the soils of the Sh. Rashidovsky region, soil contamination with heavy metals have been studied.

The parameters of the soils of the experimental site in Sh. Rashidovsky district are given in table 1. During the survey of soil pollution with heavy metals, the concentration of heavy 
metals in the soil in the layers $(0-10,10-20,20-30,30-40,40-50,50-60,60-70 \mathrm{~cm})$ of agricultural land was analyzed.

Table 1. Chemical analysis of soil

\begin{tabular}{|c|c|c|c|c|c|c|c|c|c|c|}
\hline \multirow{2}{*}{ № } & \multirow{2}{*}{$\begin{array}{c}\text { Layer, } \\
\text { sm }\end{array}$} & \multicolumn{8}{|c|}{ Chemical in soil, mkg/g, mg/kg, g/t } \\
\cline { 3 - 11 } & $\mathbf{C u}$ & $\mathbf{Z n}$ & $\mathbf{C r}$ & $\mathbf{M n}$ & $\mathbf{N i}$ & $\mathbf{C o}$ & $\mathbf{A s}$ & $\mathbf{C d}$ & $\mathbf{P b}$ \\
\hline 1 & $0-10$ & 700 & 670 & 760 & 520 & 590 & 24 & 15 & 4,60 & 2,9 \\
\hline 2 & $10-20$ & 620 & 320 & 740 & 480 & 480 & 14 & 16 & 3,4 & 2,6 \\
\hline 3 & $20-30$ & 360 & 210 & 700 & 420 & 160 & 8 & 18 & 1,7 & 1,6 \\
\hline 4 & $30-40$ & 70 & 110 & 610 & 180 & 130 & 6 & 14 & 1,2 & 1,4 \\
\hline 5 & $40-50$ & 62 & 92 & 170 & 140 & 100 & 5 & 12 & 0,3 & 1,2 \\
\hline 6 & $50-60$ & 42 & 60 & 140 & 100 & 90 & 3 & 10 & 0,2 & 1,6 \\
\hline 7 & $60-70$ & 31 & 54 & 100 & 75 & 60 & 3 & 8 & 0,1 & 1,4 \\
\hline 8 & $70-80$ & 28 & 40 & 84 & 62 & 32 & 2 & 6 & 0,1 & 1,1 \\
\hline & MCL & 33 & 23 & 200,0 & 1500 & 85 & 5,0 & 2,0 & 0,5 & 20 \\
\hline
\end{tabular}

The analysis results show that the concentration of copper is 21.2 times higher in the 0 $30 \mathrm{~cm}$ layer, 1.88 times in the $30-50 \mathrm{~cm}$ layer, the zinc concentration is higher in the $0-30 \mathrm{~cm}$ layer. 24.8 times, in the $30-50 \mathrm{~cm}$ layer. cm. 4 times in a layer of $50-70 \mathrm{~cm} .2 .8$ times from the MCL norm (Fig.3)

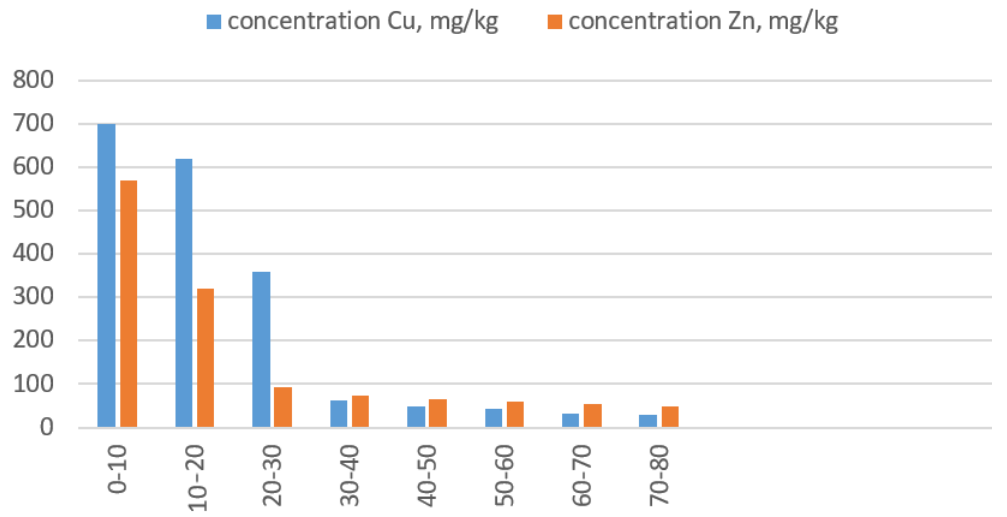

Fig. 3. Concentration of cuprum and zinc in soils o f agricultural land in Sh. Rashidov district

The concentration of chromium at point №. 1 in the $0-30 \mathrm{~cm}$ layer is $760 \mathrm{mg} / \mathrm{kg}(3.8$ MCL), in the $30-50 \mathrm{~cm}$ layer $-170 \mathrm{mg} / \mathrm{kg}(0.85 \mathrm{MCL})$, in the $50-70 \mathrm{~cm}$ layer $-100 \mathrm{mg} / \mathrm{kg}$ $(0.5 \mathrm{MCL})$. The concentration of manganese in the layer in the $0-30 \mathrm{~cm}$ layer is $520 \mathrm{mg} / \mathrm{kg}$ $(0.35 \mathrm{MCL})$, in the $30-50 \mathrm{~cm}$ layer $-140 \mathrm{mg} / \mathrm{kg}(0.09 \mathrm{MCL})$, in the $50-70 \mathrm{~cm}$ layer $-75 \mathrm{mg} / \mathrm{kg}$ $(0.05 \mathrm{MCL})$. The concentration of chromium is exceeded in layers of $0-30 \mathrm{~cm} .3 .8$ times from the MCL norm, the concentration of manganese does not exceed in three layers (Fig. 4). 


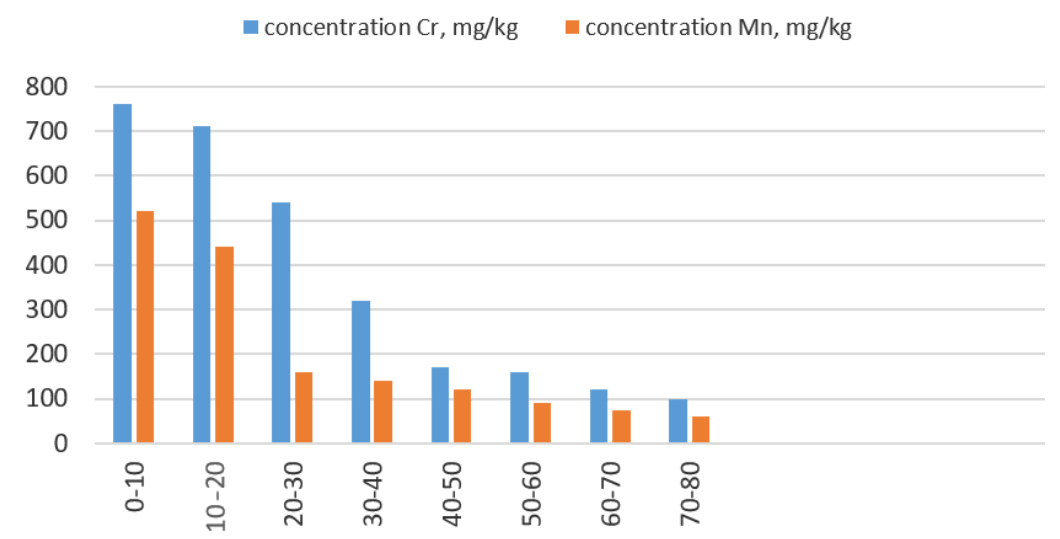

Fig. 4. Concentration of chromium and manganese in the soils of agricultural land in Sh. Rashidov district

Nickel concentration at point №. 1 in the $0-30 \mathrm{~cm}$ layer is $590 \mathrm{mg} / \mathrm{kg}(6.9 \mathrm{MCL})$, in the $30-50 \mathrm{~cm}$ layer $-100 \mathrm{mg} / \mathrm{kg}(1.18 \mathrm{MCL})$, in the $50-70 \mathrm{~cm}$ layer $-32 \mathrm{mg} / \mathrm{kg}(0.38 \mathrm{MCL})$. Exceed the MCL from the norm 6.9 times in the $0-30 \mathrm{~cm}$ layer, 1.18 times in the $30-50 \mathrm{~cm}$ layer (Fig. 5).

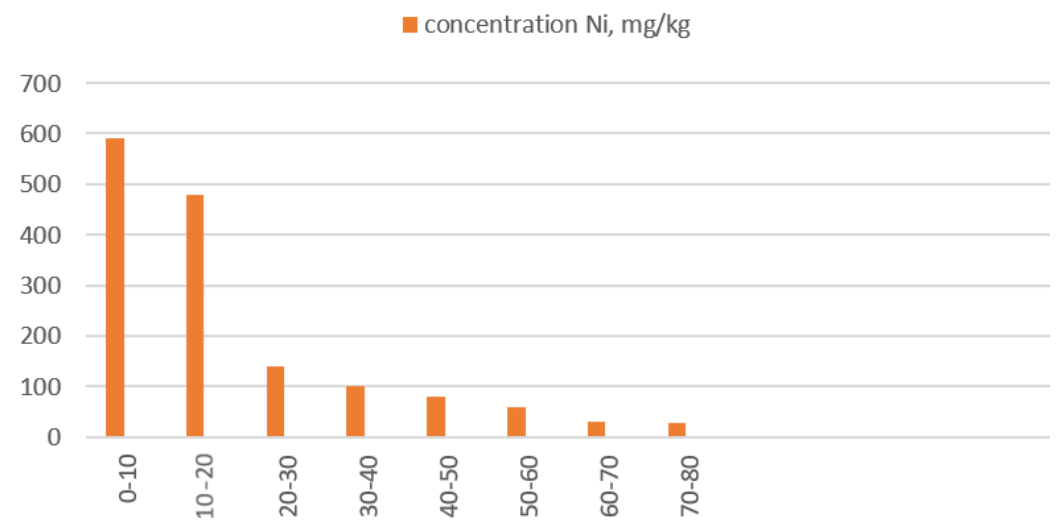

Fig. 5. Nickel Concentration in Soils of Agricultural Lands of Sh. Rashidovsky District

The concentration of cobalt at point №. 1 in the $0-30 \mathrm{~cm}$ layer is $24.0 \mathrm{mg} / \mathrm{kg}$ (4.8 MCL), in the $30-50 \mathrm{~cm}$ layer $-5.6 \mathrm{mg} / \mathrm{kg}(1.12 \mathrm{MCL})$, in the $50-70 \mathrm{~cm}-2.7 \mathrm{mg} / \mathrm{kg}(0.54 \mathrm{MCL})$. The concentration of arsenic in the layer in the $0-30 \mathrm{~cm}$ layer is $15 \mathrm{mg} / \mathrm{kg}$ (7.5 MCL), in the $30-50 \mathrm{~cm}$ layer $-17 \mathrm{mg} / \mathrm{kg}$ (8.5 MCL), in the $50-70 \mathrm{~cm}$ layer $-12 \mathrm{mg} / \mathrm{kg}(6.0 \mathrm{MCL})$. The concentration of cobalt is exceeded in layers $0-30 \mathrm{~cm}$. 4.8 times, in layers $30-50 \mathrm{~cm} .1 .12$ times, the concentration of arsenic is exceeded in the layer $0-30 \mathrm{~cm} .7 .5$ times, in the layer $30-50 \mathrm{~cm}$. 8.5 times, in layers of 50-70 cm. 6.0 times from the MPC norm (Fig. 6). 


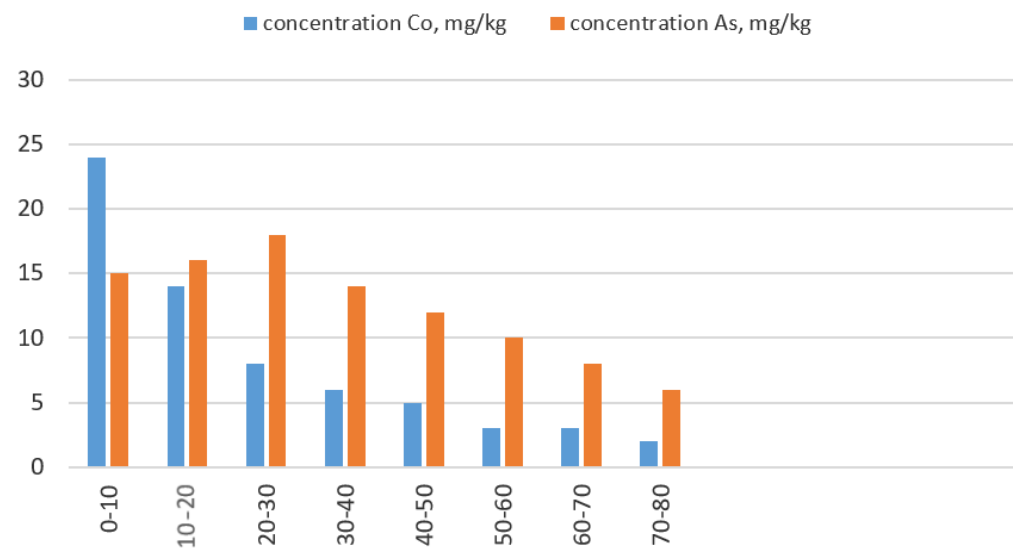

Fig. 6. Concentration of cobalt and arsenic in the soils of agricultural land in Sh. Rashidovsky district

The concentration of cadmium at point №. 1 in the $0-30 \mathrm{~cm}$ layer is $4.6 \mathrm{mg} / \mathrm{kg}(9.2 \mathrm{MCL})$, in the $30-50 \mathrm{~cm}$ layer $-0.2 \mathrm{mg} / \mathrm{kg}(0.4 \mathrm{MCL})$, in the $50-70 \mathrm{~cm}-0.08 \mathrm{mg} / \mathrm{kg}(0.16 \mathrm{MCL})$. The lead concentration in the layer in the $0-30 \mathrm{~cm}$ layer is $2.9 \mathrm{mg} / \mathrm{kg}(0.14 \mathrm{MCL})$, in the $30-50$ $\mathrm{cm}$ layer $-1.6 \mathrm{mg} / \mathrm{kg}(0.08 \mathrm{MCL})$, in the $50-70 \mathrm{~cm}$ layer $-1.6 \mathrm{mg} / \mathrm{kg}(0.08 \mathrm{MCL})$. The concentration of cadmium in layers of $0-30 \mathrm{~cm}$ is 9.2 times, in layers of $30-50 \mathrm{~cm}$ and $50-70$ $\mathrm{cm}$, the concentration of lead in three layers does not exceed the MCL norm (Fig. 7).

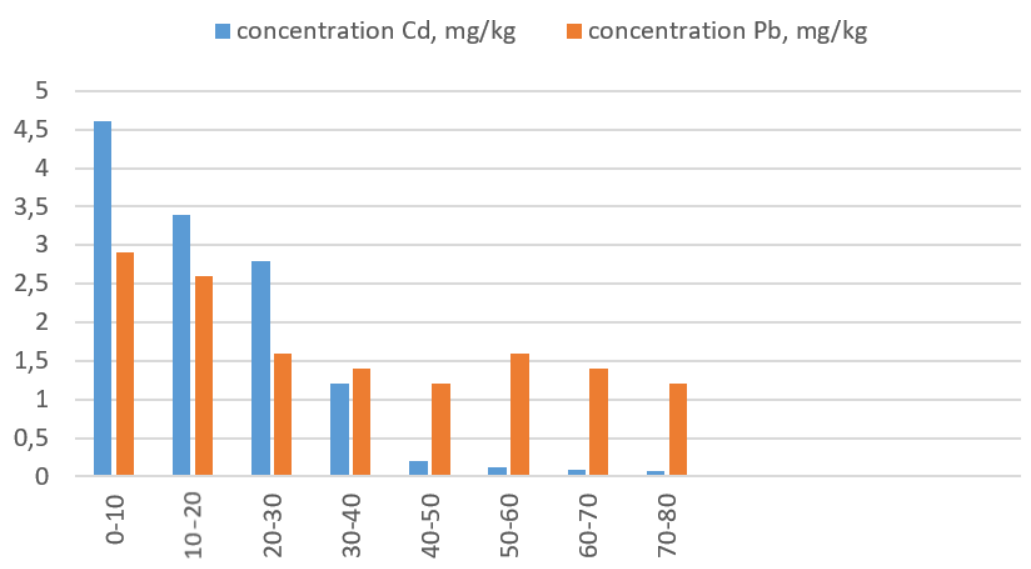

Fig. 7. Concentration of cadmium and lead in soils of agricultural land in Sh. Rashidov district

A significant role in the formation of the anthropogenic soil background is played by the ways of heavy metals entering the soil from the atmosphere. To assess the impact of vehicle emissions on soil pollution with heavy metals, we carried out statistical studies. The study of the content of heavy metals in soil samples of the territory adjacent to the highway showed that most of it was within and exceeded the permissible concentration.

\section{Conclusions}

Analysis of soil contamination with heavy metals at the research site in Sh. Rashidovsky district shows that most of the pollutants were found in soil samples. Analysis of soil pollution with heavy metals in the territory shows that a slight increase in the MPC for soils was observed for cuprum, zinc, chromium, manganese, nickel, cobalt, arsenic, cadmium, and lead. The excess occurred mainly in the upper layer of 0-30 centimeters. The concentrations 
of all other heavy metals do not exceed the MPL, which confirms the conclusions drawn in the review section of the study on the low informative value of heavy metals in environmental monitoring.

To reduce the negative impact of heavy metals on the light gray lands of the Sh. Rashidov region, it is necessary:

- $\quad$ application of mineral fertilizers (for example, phosphate fertilizers, reduces toxic

the action of lead, copper, zinc, cadmium);

- growing crops resistant to pollution.

To improve their reclamation state, soil fertility and increase the productivity of agricultural crops, it is recommended to introduce composts prepared on the basis of poultry manure, phosphogypsum and glauconite. Determine the optimal components for the preparation of ameliorants and organomineral composts, determine their absorption capacity for heavy metals and their effect on the chemical, physicochemical, physical and agrochemical properties of ordinary terraced irrigated soil in laboratory and field experiments.

\section{References}

1. Alexandrova L.N. Soil organic matter and processes of its transformation. (Science, Leningrad, 1980)

2. A.I. Vezentsev, M.A. Trubitsyn, L.F. Goldovskaya-Peristaya, N.A. Volovicheva, Scientific Bulletin of Belgorod State University, 3(43) (2008)

3. Pavlichenko L.M. and other., Int. J. of Applied and Basic Research, 2-1, 53-58. (2016)

4. L.R. Gazilova, S.I. Yantkrin,G.A. Yagafarova, OSU Bulletin, 6 (100), 552-553 (2009)

5. D.Yu. Makhkamova, O.Kh. Ergasheva, Soil science - food and ecological safety of the country. VII Congress of the Dokuchev Soil Science Society. Materials of reports part 2, 123-124 (2016).

6. S.A. Abdullaev, M.A.Mazirov, Z.U. Rakhmatov, In: Implementation of the methodological and methodological ideas of Professor BA Dospekhov in the improvement of adaptive landscape farming systems. (Collective monograph) (Press-Sto Publishing House, Moscow-Suzdal, 2017)

7. Harmful Chemical Substances: Inorganic Compounds of Group I - IV Elements, (Chemistry, Leningrad, 1988)

8. GOST 17.4.3.01-83 (ST SEV3847-82). Protection of Nature. Soils. General requirements for sampling. (Goskomsanizdat, Moscow, 1984).

9. GOST 17.4.3.06-86 (ST SEV5301-85). Protection of Nature. Soils. General requirements for the classification of soils according to the effect on them of chemical scowpollutants. - (Goskomsanizdat, Moscow, 1987)

10. Guidelines for the determination of heavy metals in agricultural soils and crop production. (TsINAO, Moscow) 